\title{
Зоряна Гбур
}

доктор наук з державного управління, професор, професор кафедри управління охороною здоров'я та публічного адміністрування, Національний університет охорони здоров'я України імені П. Л. Шупика, м. Київ, Україна, e-mail: ernest-natan@ukr.net,https://orcid.org/0000-0003-4536-2438

\section{СОЦАЛЬНЕ СТРАХУВАННЯ ЯК БАЗОВИЙ ЕЛЕМЕНТ ДЕРЖАВНОЇ ПОЛТТИКИ ЩОДО ПРАЦЕЗДАТНОГО НАСЕЛЕННЯ}

Анотація. В статті розглянуто питання функціонування та розвитку соціального страхування як механізму реалізації державної політики щодо працездатного населення. В даний час кожен учасник страхової діяльності стикається 3 проблемами в рамках формування, перерозподілу та отримання коштів. Соціальне страхування представляє собою один із засобів реалізації соціальної складової економічної системи. Основним принципом його функціонування $є$ фінансова реалізація конституційних прав та гарантій громадян. Визначено, що роль соціального страхування полягає у: 1) формуванні економічних, організаційних i правових механізмів щодо соціального захисту матеріального становища працездатного населення від соціальних ризиків; 2) встановленні взаємозв'язку між економічною та соціальною формами людської життєдіяльності; 3) створенні організаційноуправлінських механізмів, структур та систем гарантії, що мають на меті надання громадянам матеріального забезпечення у вигляді допомоги, пенсій, послуг 3 лікування та реабілітації. Основним завданням державної політики з соціального страхування є надання соціальної допомоги особам, що іï потребують, зокрема: забезпечення мінімального рівня доходів інвалідам, пенсіонерам, малозабезпеченим, захист громадян у випадку хвороби, забезпечення доступу до певних благ. Обгрунтовано, що соціальне страхування $\epsilon$ основною формою соціального захисту населення за об'ємом фінансових ресурсів, масовості охоплення, різноманітністю послуг та виплат. Однак, до теперішнього часу в процесі його становлення визначились суттєві проблеми, що є перешкодою для подальшого розвитку як безпосередньо соціального страхування, так і соціальноекономічних відносин в країні в цілому. Виявлено, що існуюча система обов'язкового соціального страхування потребує суттєвої модернізації, вектор ііі розвитку полягає в формуванні повноцінного інституту соціального страхування, залученні до більшої участі в функціонуванні страхових механізмів іiї суб'єктів: роботодавців, працездатного населення та держави. Нова модель соціального страхування потребує підвищення демократичності в управлінні з боку держави.

Ключові слова: соціальний захист, соціальне страхування, державна політика, фонди соціального страхування, соціальні ризики. 


\title{
Zoriana Hbur
}

Doctor of Sciences in Public Administration, Full Professor, Professor of the Department of Healthcare Management and Public Administration, Shupyk National Healthcare University of Ukraine Kyiv, Ukraine, e-mail: ernest-natan@ukr.net, https://orcid.org/0000-0003-4536-2438

\section{SOCIAL INSURANCE AS A BASIC ELEMENT OF STATE POLICY REGARDING THE WORKING POPULATION}

\begin{abstract}
The article considers the functioning and development of social insurance as a mechanism for implementing state policy on the working population. Currently, each participant in the insurance business faces problems in the formation, redistribution and receipt of funds. Social insurance is one of the means of implementing the social component of the economic system. The main principle of its functioning is the financial realization of constitutional rights and guarantees of citizens. It is determined that the role of social insurance is:

1) the formation of economic, organizational and legal mechanisms for social protection of the financial situation of the working population from social risks; 2) establishing the relationship between economic and social forms of human life; 3) creation of organizational and managerial mechanisms, structures and guarantee systems aimed at providing citizens with material support in the form of assistance, pensions, treatment and rehabilitation services. The main task of the state policy on social insurance is to provide social assistance to people in need, in particular: ensuring a minimum level of income for the disabled, pensioners, the poor, protection of citizens in case of illness, access to certain benefits. It is substantiated that social insurance is the main form of social protection of the population in terms of financial resources, mass coverage, variety of services and benefits.However, to date, in the process of its formation, significant problems have been identified, which is an obstacle to the further development of both direct social insurance and socio-economic relations in the country as a whole. It was found that the existing system of compulsory social insurance needs significant modernization, the vector of its development is the formation of a full-fledged institution of social insurance, involvement in greater participation in the functioning of insurance mechanisms of its subjects: employers, working population and the state. The new model of social insurance requires increased democracy in the management of the state.
\end{abstract}

Keywords: social protection, social insurance, state policy, social insurance funds, social risks.

Постановка проблеми. Протягом останнього часу питанням соціального страхування приділяється значна увага як зі сторони вчених та держави, так і 3 боку населення. Науковці розглядають даний сегмент як поле для дослідження виникаючих питань та їх вирішення на рівні співставлення теоретичних та 
практичних напрацювань. Держава виступає в цьому напрямку як гарант виконання завдань, обов’язків та подальшого розвитку соціального страхування в рамках проведення тої чи іншої державної політики. Працездатне населення націлено на страховий захист та забезпечення у майбутньому та у разі виникнення непередбачених випадків.

Розвинутий інститут соціального страхування $\epsilon$ основою соціальної справедливості та стабільності в державі. Враховуючи значимість цього соціального інституту, в багатьох країнах йде процес створення та реформування системи обов'язкового державного соціального страхування, що забезпечує надійний соціальний захист населення.

Ризикова природа людського існування є основою для виникнення різних механізмів захисту від ризику. Ризик - це поняття, що характеризує потенційну можливість настання збитку. На цьому підгрунті закономірно виникла ідея відшкодування можливого збитку шляхом солідарного його розподілу між зацікавленим колом осіб. В ринковій економіці одним 3 найважливіших елементів $\epsilon$ наявність розвинутої системи соціального захисту громадян: соціальна допомога, соціальне забезпечення та соціальне страхування. При цьому головним інститутом соціального захисту людини є саме соціальне страхування, спрямоване на зменшення та запобігання соціальним ризикам, воно виступає пріоритетним напрямом у здійсненні соціальної політики держави. Соціальне страхування скеровано на активне працездатне населення та враховує можливі соціальні ризики втрати доходу та прибутку найманими особами.

Обов'язкове соціальне страхування $\epsilon$ елементом державної системи соціального захисту населення, специфікою якої $\epsilon$ здійснення відповідно до вітчизняного законодавства страхування працездатного населення від можливої зміни матеріального та соціального положення, в тому числі від не залежних від них умов. Воно знаходить багато проявів. У їх склад входять як нормативноправові, економічні, так і організаційні заходи, що існують для стабілізації соціального та матеріального становища застрахованих громадян при настанні певних ризиків, зокрема, втрати роботи, здоров'я, працездатності, також настанні страхових випадків.

У зв'язку з цим подальше дослідження сутності та питань функціонування соціального страхування, розробка перспективних напрямів його подальшого розвитку, які сприяли б вирішенню певних проблем та становленню його на міцну страхову основу, є доволі актуальним в теоретичному та практичному плані.

Аналіз останніх досліджень і публікацій. Проблеми формування та розвитку системи соціального страхування знайшли висвітлення в наукових працях таких вітчизняних учених-економістів: Н. Абакумової, Н. Борецької, В. Гейця, В. Гетьмана, А. Гриненко, О. Гупала, К. Дідківської, О. Длугопольського, Ю. Килимника, О. Коваль, Е. Лібанової, О. Макарова, В. Новікова, О. Палій, І. Рудкевич, І. Сироти, А. Сіленко, А. Халецької, П. Шевчука та інших. Однак, попри значну кількість праць, що присвячені проблемам функціонування та реалізації системи соціального страхування, існує 
необхідність детальнішого розгляду наявної системи соціального страхування, що забезпечуватиме достатній рівень і якість життя громадян України в сучасних умовах.

Мета статті полягає у дослідженні ролі та особливостей соціального страхування як базового елементу державної політики сучасної України.

Виклад основного матеріалу. Сучасні системи соціального страхування виступають в якості основи соціального захисту населення в розвинутих країнах. Вони наділені гнучкістю та адаптивністю в міру того, що грунтуються на принципах страхування. Це дозволяє їм відповідати реаліям ринкової економіки.

Соціальне страхування представляє собою один із способів реалізації соціальної складової економічної системи. Основними принципами функціонування фондів соціального страхування $€$ фінансова реалізація конституційних прав та гарантій громадян.

Сучасна система соціального захисту населення включає наступні основні елементи:

- державне соціальне забезпечення (соціальну допомогу);

• сукупність державних гарантій, включаючи надання соціальних пільг окремим категоріям населення;

- соціальне страхування.

Принцип - зміни стимулів, який впливає на людську поведінку, людина орієнтована на вибір способу дій, що забезпечує їй найбільші вигоди і найменші витрати - не спрацьовує, при цьому виникають суперечності між індивідуальними і суспільними інтересами, які неможливо узгодити ринковими механізмами. Для вирішення суперечностей $є$ державне регулювання в рамках соціального страхування.

У. Беверідж одним 3 перших запропонував визначення соціального страхування виходячи 3 його основної функції - відшкодування втраченого заробітку. На його думку, соціальний захист означає “захист за рахунок надання доходу замість заробітку, коли він переривається безробіттям, хворобою або нещасним випадком, за рахунок забезпечення пенсією, за рахунок забезпечення підтримки у разі втрати годувальника сім’ї та покриття непередбачених витрат, пов'язаних 3 народженням, смертю або шлюбом”. У. Беверідж постійно наголошував, що цей захист має бути мінімальним та сприяти швидшому закінченню “перерви у заробітку” [1].

Для розгляду більш докладного розуміння проблематики дослідження, спочатку дамо головні характеристики понять - держава, політика, державна політика, страхування, соціальне страхування. Так, на думку багатьох вчених, держава розглядається як зовнішній регулятор, що здійснює регуляторне втручання та знаходить «точку рівноваги» індивідуальних і суспільних інтересів.

Політика в традиційному розумінні інтерпретується як середовище взаємодії між різними соціальними групами, партіями, націями, народами, державами, владою і населенням, а також громадянами та їх об’єднаннями.

Під державною політикою слід розуміти сукупність ціннісних цілей, 
державно-управлінських заходів, рішень і дій, порядок реалізації державнополітичних рішень (поставлених державною владою цілей) і системи державного управління розвитком країни.

Страхування - це вид цивільно-правових відносин щодо захисту майнових інтересів фізичних осіб та юридичних осіб у разі настання певних подій (страхових випадків), визначених договором страхування або чинним законодавством, за рахунок грошових фондів, що формуються шляхом сплати фізичними особами та юридичними особами страхових платежів (страхових внесків, страхових премій) та доходів від розміщення коштів цих фондів [9].

Соціальна сутність сучасної держави виражається в іiі функціях щодо освіти, культури, охорони здоров'я, пенсійного забезпечення та інших форм соціального захисту своїх громадян. Держава набуває соціальних ознак, якщо реалізація зазначених функцій відбувається на основі панування права, забезпечення гарантій прав людини, дотримання демократичних принципів здійснення соціально-економічної політики.

Соціальна держава спрямовує свою політику в напрямок розвитку ринкової економіки, соціальної справедливості, соціальної захищеності, соціального партнерства і соціальної солідарності суспільства. Її основними завданнями є: досягнення високого рівня життя населення, захист та реалізація прав і свобод громадян, створення сучасних систем соціального забезпечення, підтримка малозабезпечених та бідних соціальних верств, запобігання i вирішення соціальних конфліктів [4].

3’ясуємо поняття соціального страхування та його необхідність на рис. 1.

Соціальне страхування - складова соціального захисту населення, центром якого $€$ людина та їі потреби, а рівень соціальної захищеності людини у більшій або меншій мірі стимулює соціально-економічний розвиток держави в цілому.

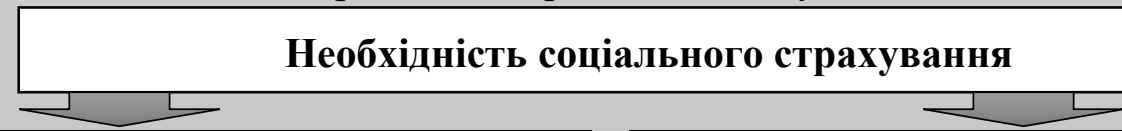

наявність громадян, що не беруть участі у суспільно корисній праці, а тому не можуть утримувати себе за рахунок заробітної плати (доходу від підприємницької діяльності)

наявність громадян, що є дієздатними, але не мають можливості 3 різних причин пі реалізувати

\section{Рис. 1. Значення сочіального страхування}

Джерело: складено на основі [5].

Завдяки соціальному страхуванню суспільство вирішує такі завдання [8]:

-формує грошові фонди, 3 яких фінансуються витрати, що пов’язані 3 утриманням непрацездатних осіб;

-забезпечує необхідну кількість і структуру відтворення трудових ресурсів;

-скорочує розриви в рівні матеріального забезпечення працюючого та непрацюючого населення; 
-досягає підвищення життєвого рівня соціальних груп населення, які не беруть участі в трудовому процесі.

У термінології щодо соціального страхування, ми стикаємось 3 такою дефініцією як соціальний захист.

Отже, соціальний захист - це комплекс правових, економічних та соціальних гарантій, що забезпечує держава кожному громадянину: право на безпечну працю, збереження здоров'я у процесі праці, економічний захист і підтримку працівників та їх сімей у випадку тимчасової втрати працездатності на виробництві, медичну і професійну реабілітацію [12; 13].

Соціальне страхування відрізняється від інших елементів соціального захисту за наступними ознаками:

-соціальне страхування розповсюджується на працездатне населення та членів їх сімей та регулюється державою;

- фінансовою основною соціального страхування $\epsilon$ формування 3 внесків працівників та роботодавців спеціальних фондів, кошти яких розподіляються між учасниками, що отримали збиток від дії соціального ризику;

•соціальні виплати визначаються розмірами, термінами та іншими умовами сплати страхових внесків;

- право на отримання страхових виплат визначається тільки виконанням обов'язків щодо сплати внесків та фактом настання соціального ризику без додаткової перевірки потреби в доході;

•обов'язок зі сплати внесків у соціальне страхування спільно несуть працівники та роботодавці із залученням за необхідністю фінансової участі держави.

Механізм соціального страхування наділений важливими параметрами та характеристиками соціального інституту, зокрема [10]:

•наявність суб’єктно-об'єктної структури, елементами якої виступають працівники, страховики, страхувальники та соціальний ризик, пов'язаний iз втратою заробітку;

- наявність системи нормативного регулювання соціального страхування;

-організаційна структура, заснована на позабюджетних фондах, що знаходяться у власності держави, але не асоційовані із державним бюджетом;

•здійснення соціальних гарантій.

Далі розглянемо складові, що формують систему соціального страхування на рис. 2 . 


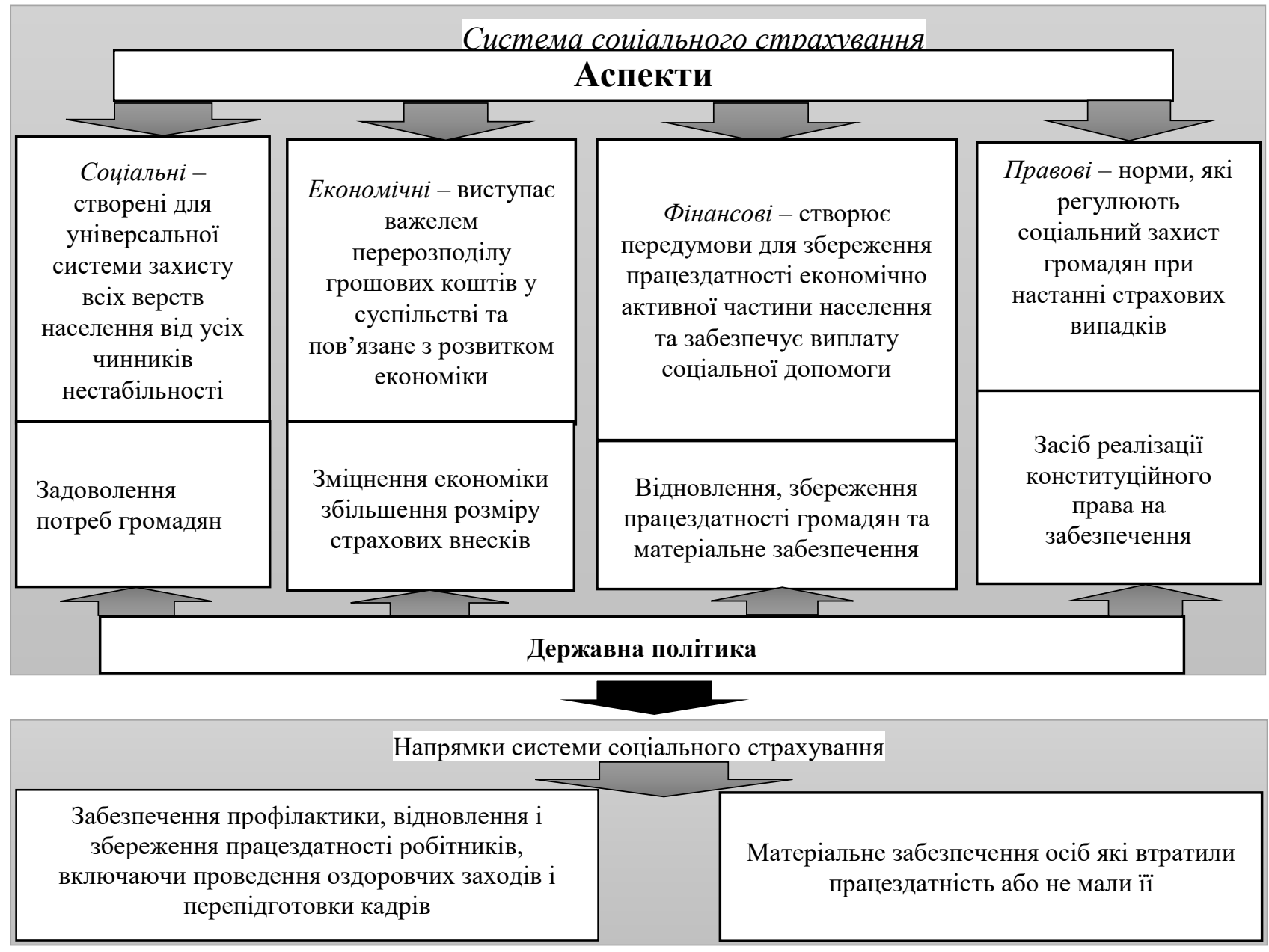

Рис.2. Система соиіального страхування

Джерело: складено на основі [11].

Згідно представленого рисунку зрозуміло, що наявність системи соціального страхування $є$ базовим елементом державної політики, яка реалізує відповідно напрямків сукупність економічних, фінансових, соціальних та правових відносини, що виникають у результаті соціального захисту населення при настанні страхових випадків, задоволенні потреб громадян, розвитку економіки у відновленні й збереженні працездатності громадян та гарантуванні їм матеріального забезпечення.

Однак, потрібна відповідна державна політика, спрямована на досягнення цілей, що ставить суспільство перед владою. Однією з таких цілей є соціальний захист громадян.

Отже, політика щодо соціального захисту має грунтуватися на таких принципах:

-персональна відповідальність найманих працівників, їх роботодавців, інших категорій працюючих і працездатних осіб за фінансове забезпечення прийнятного рівня соціального захисту;

•солідарна підтримка працюючим населенням і роботодавцями найменш захищених категорій населення та їх сімей; 
• оптимальна підтримка (принцип субсидіарності), що визначає міру (межі) солідарної підтримки, фіксує їі розмір і форми надання.

Соціальний захист полягає у реалізації основних напрямів соціальної політики завдяки комплексу організаційно-правових і соціально-економічних заходів.

Ці заходи направлені на соціальне забезпечення населення. Тому зазначимо, що соціальне забезпечення - це система державних заходів щодо надання матеріальної допомоги 3 метою компенсації, зниження або запобігання негативного впливу соціальних ризиків на осіб, які через незалежні від них життєві обставини не мають достатніх засобів до існування [12; 13].

Соціальне забезпечення полягає i в безпосередньому наданні державою грошових виплат особам, які мають на них право, і в забезпеченні соціального утримання, наданні медичної допомоги, безоплатному (без еквівалентному) або на пільгових умовах обслуговуванні громадян.

Сьогодні в процесі історичного розвитку сформувалися та функціонують наступні моделі соціального захисту (рис.3).

\begin{tabular}{|c|c|c|}
\hline & \multicolumn{2}{|c|}{ Моделі соціального страхування } \\
\hline $\begin{array}{l}\text { Ліберальна } \\
\text { (англоамериканська) }\end{array}$ & $\begin{array}{l}\text { Консервативна } \\
\text { (корпоративна) }\end{array}$ & $\begin{array}{l}\text { Соціально-- } \\
\text { демократична }\end{array}$ \\
\hline $\begin{array}{l}\text { - втручання держави } \\
\text { мінімальне; } \\
\text { - державні заходи } \\
\text { зводяться до встановлення } \\
\text { невисоких єдиних тарифних } \\
\text { ставок у галузі пенсійного } \\
\text { страхування та інше }\end{array}$ & 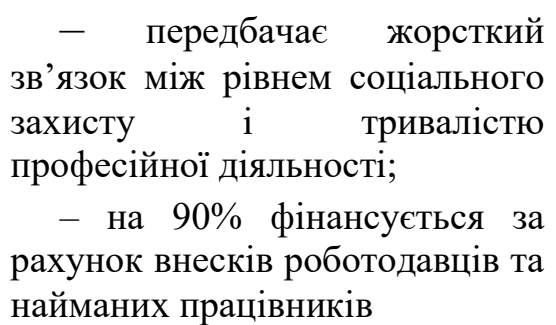 & \begin{tabular}{lrr}
\multicolumn{1}{c}{ - держава } & надає & всім \\
громадянам & широке & коло \\
гарантій, пільг і соціальної \\
підтримки & в & межах \\
державного & соціального \\
забезпечення & 3 & високим \\
рівнем дотацій & &
\end{tabular} \\
\hline
\end{tabular}

\section{Рис. 3. Моделі соціального страхування}

Джерело: складено на основі [7].

Зауважимо, що не тільки моделі, але й системи соціального страхування в різних країнах світу дуже різняться між собою. Це обумовлено економічним розвитком конкретних країн, пріоритетними напрямками соціальної політики держав, взаємодією приватного i державного секторів у галузі соціального страхування, джерелами його фінансування, демографічною ситуацією, рівнем матеріальної допомоги. Кожна 3 цих моделей соціального страхування має свої переваги та недоліки і практично не зустрічається в чистому вигляді. У кожній конкретній країні зазвичай можна спостерігати сполучення елементів ліберальної, корпоративної та соціал-демократичної моделей за явної переваги 
однієї з них. Усі вони при цьому постійно розвиваються та вдосконалюються [3]. Даним світовим моделям соціального страхування притаманні наступні характеристики:

- основні види соціального страхування носять обов’язковий характер;

- перерозподіл частини національного доходу між окремими групами населення на основі принципу еквівалентності, та розподіл матеріальної відповідальності за соціальні ризики між застрахованими, роботодавцями та державою;

- $\quad$ соціальні виплати фінансуються за рахунок створення страхових фондів грошових засобів, які в основному формуються за рахунок внесків роботодавців та працівників (існує їх пайова участь);

- кошти від поступлень, що перевищують видатки на соціальне страхування, інвестуються з метою отримання додаткових доходів;

- $\quad$ захист від конкретних видів соціального ризику організований в рамках окремих напрямків соціального страхування;

- $\quad$ розмір страхових внесків залежить від величини заробітної плати або доходу застрахованого;

- $\quad$ регулювання соціального страхування здійснюється на основі поєднання публічно-правового та державного управління [6].

Вітчизняна модель соціального захисту передбачає активну роль держави не тільки в соціальному забезпеченні, яке здійснюється за рахунок бюджетних коштів, а й у соціальному страхуванні, організацію якого бере на себе держава. Проте, на відміну від подібних систем в інших країнах, що базуються, переважно, на обов'язковому державному соціальному страхуванні, здійснюваному як державними, так і приватними організаціями і органічно вбудованому в систему соціального захисту, в Україні соціальне страхування є тільки державним. Це призводить до порушення страхових принципів його організації та до необгрунтованої конвергенції соціального страхування і соціального забезпечення [2].

В Україні згідно законодавства діє три фонди соціального страхування. Структуру державних органів, що забезпечують систему соціального страхування подано на рис. 4.

В Україні на даний час діють три цільові позабюджетні фонди, зокрема:

1. Пенсійний фонд України (ПФУ).

2. Фонд соціального страхування України (ФСС), який здійснює керівництво та управління загальнообов'язковим державним соціальним страхуванням від нещасного випадку, у зв’язку з тимчасовою втратою працездатності та медичним страхуванням.

3. Фонд загальнообов'язкового державного соціального страхування України на випадок безробіття (ФБ).

При цьому відбувається класична ланцюгова модель: “страхувальник (роботодавець) - страховик (фонд) - застрахована особа (працівник)”. 


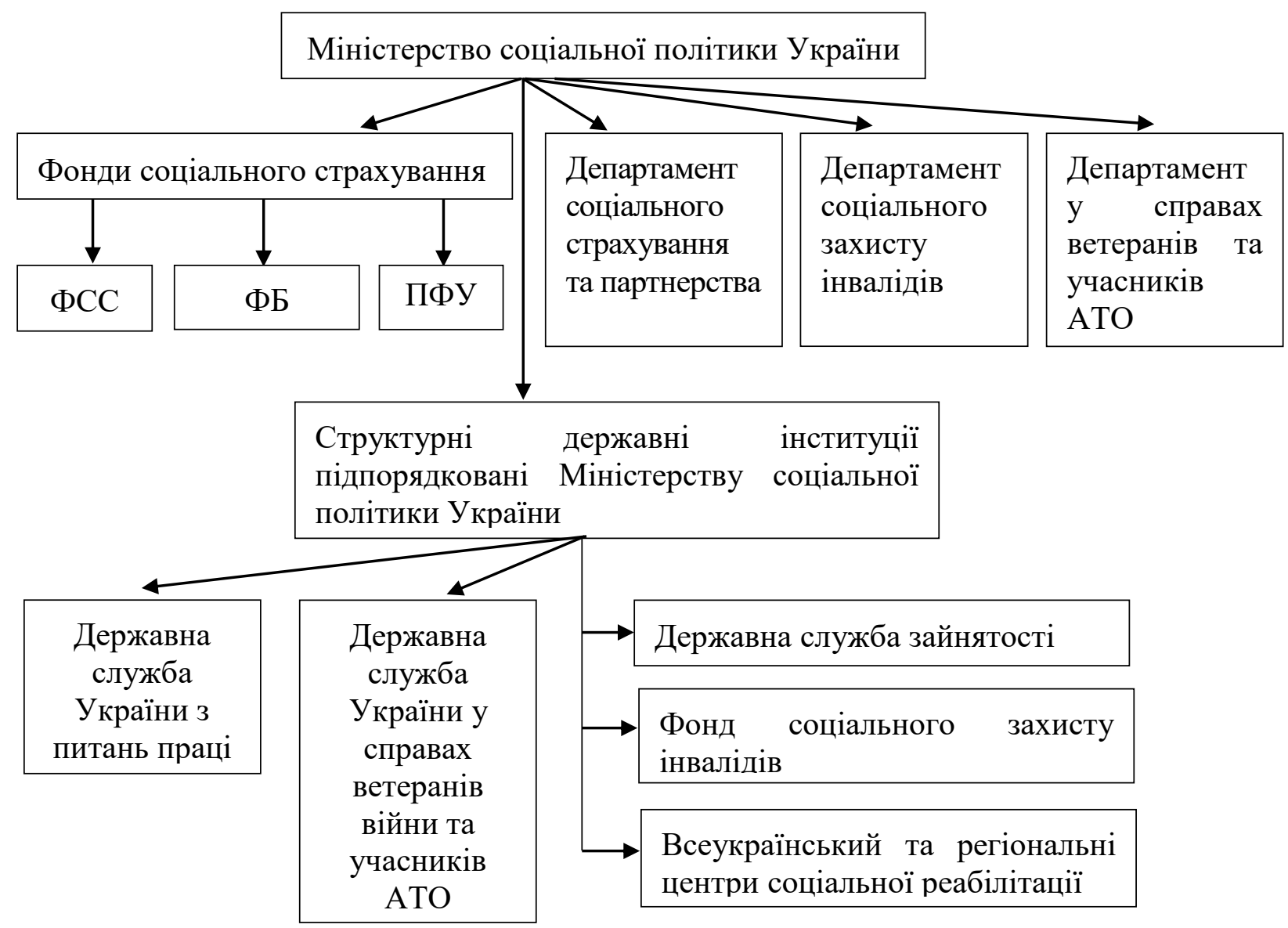

Рис. 4. Державні органи, щуо здійснюють діяльність з соиіального страхування

Джерело: складено на основі [7; 8].

В подальшому стратегія розвитку соціального страхування повинна включати консолідовану позицію держави та роботодавців у вирішенні питань в галузі соціального страхування; активізацію роботи профспілок при збереженні за державою законодавчих та контрольних функцій; створення умов та передумов для розвитку недержавного соціального страхування, що, в першу, чергу пов'язано з організацією недержавних пенсійних фондів.

Висновки. Система соціального страхування як економічна основа сприяє вирішенню соціальних проблем та тим самим реалізує соціальну складову економічної системи. Особливості соціального страхування, що носять негативний характер, незмінно тягнуть за собою виникнення нових проблем різного характеру, що позначається на економічній системі в цілому. Крім того стоїть питання про справедливість розподілу фінансових ресурсів між різними верствами суспільства.

Важливою умовою створення ефективної системи соціального страхування $\epsilon$ розробка чіткої системи базових орієнтирів ії побудови. Не дивлячись на велику кількість підходів до визначення принципів соціального страхування, основними принципами, що відрізняють його від інших форм соціального захисту є: 
•принцип особистої відповідальності працівників та роботодавців за організацію страхового захисту від соціальних ризиків;

-солідарної взаємодопомоги працівників та роботодавців з відшкодування витрат, пов'язаних із соціальними ризиками;

•субсидіарної відповідальності застрахованих та страхувальників у фінансових та управлінських питаннях;

•взаємної відповідальності щодо виконання суб'єктами страхових відносин встановлених законодавством обов'язків.

Сутність соціального страхування як соціального інституту розкривається за допомогою функцій, зокрема: гарантійної, економічної та регламентуючої. Виконуючи свою основну мету - компенсацію втрати трудового доходу в результаті настання соціального ризику, соціальне страхування виконує свою основну функцію - захист відтворення людини. Органічна присутність системи соціального страхування в суспільному житті та забезпечення більш повного захисту індивідів суспільства від соціальних ризиків, наявність базових орієнтирів побудови та соціально значимих функцій дозволяють говорити про соціальне страхування як про соціальний інститут.

Управління соціальним страхуванням пов'язано 3 роллю соціальних суб’єктів (роботодавців та працівників), державних органів в організації даного виду соціального захисту, оперативним регулюванням та контролем. Фонди соціального страхування представляють собою організації публічного характеру, обов'язкові для участі у їх діяльності роботодавців та працівників; позабюджетні щодо їх відокремлення від державного бюджету; страхові щодо форми акумуляції та витрачання ресурсів; адміністративно-централізовані щодо способу управлінської діяльності.

Подальший розвиток соціального страхування як базового елементу державної політики в Україні потребує впровадження таких заходів:

-реорганізація структури соціального страхування шляхом створення базового уніфікованого інституту, який би включав усі можливі види страхових випадків та забезпечував щільне правове структурування та кодифікацію всіх форм та видів захисту;

•розвиток накопичувальної системи пенсійного страхування;

-впровадження загальнообов'язкового медичного страхування 3 метою вирішення проблем системи охорони здоров'я;

-посилення прозорості роботи фондів соціального страхування шляхом своєчасного та в повному обсязі інформування суспільства про діяльність ФСС, їх результативність, упровадження нових видів соціальних послуг;

•оптимізація відношення рівня зобов'язань та фінансових ресурсів;

-визначення фінансових механізмів окремих видів та всієї системи соціального страхування з урахуванням формування оптимального навантаження суб'єктів страхування;

-підвищення ефективності адміністрування витрат в системі обов’язкового соціального страхування; 
-залучення недержавних страхових організацій для здійснення обов'язкового соціального страхування від нещасних випадків на виробництві та професійних захворювань шляхом укладення ними договорів концесії з фондом соціального страхування та обов’язковим ліцензуванням їх діяльності.

\section{Лimepamypa:}

1. Губар О.С. Соціальне страхування у забезпеченні суспільного добробуту. Фінанси України. 2012. № 8. С. 130-136.

2. Димніч О. В. Система соціального страхування та шляхи ії удосконалення в Україні : автореф. дис. ... к. е. н. : 08.00.08. Київ, 2015. 33 с.

3. Димніч О. В. Становлення систем соціального захисту громадян на страхових засадах в промислово розвинених країнах. Наука та економіка. 2013. № 4. Т. 2. С. 13-19.

4. Кириленко О. П. Толуб’яка В. С. Соціальне страхування. Тернопіль : Екон. думка THEУ, 2016. $516 \mathrm{c}$.

5. Коваль О. П. Модернізація системи соціального страхування в Україні: аналітична доповідь. Київ : НІСД, 2014. 38 с.

6. Кривошлик Т. Д. Вплив тенденцій соціального страхування на розвиток системи страхового захисту в Україні. Бізнес інформ. 2018. № 12. C.239-245. URL: https://www.businessinform.net/export_pdf/business-inform-2018-12_0-pages-239_245.pdf (дата звернення: 22.12.2020).

7. Кропельницька С. О., Солоджук Т. В. Соціальне страхування. Київ : Центр учбової літератури, 2013. $336 \mathrm{c.}$

8. Макарова О. В. Соціальна політика в Україні : монографія. Київ : Ін-т демографії та соціальних досліджень ім. М. В. Птухи НАН України, 2015. 244 с.

9. Про страхування [Електронний ресурс]: Закон України №85/96-BP від 07.03.1996. URL: https://zakon.rada.gov.ua/laws/show/85/96-\%D0\%B2\%D1\%80\#Text (дата звернення: 22.12.2020).

10. Серватинська I.M. Фінансове забезпечення функціонування державних фондів соціального страхування : дис. ... к.е.н. : 08.00.08. Черкаси, 2016. 276 с.

11. Скуратівський В. А., Палій О. М. Основи соціальної політики : навч. посібник. Київ : Міжрегіональна академія управління персоналом, 2010. 200 с.

12. Устинов С. О. Співвідношення термінів «соціальний захист» та «соціальне забезпечення» в законодавстві України. Юридична наука і практика. 2011. № 2. С. 90-95.

13. Шульга, Н. В. Співвідношення понять «соціальне забезпечення» та «соціальний захист». Митна справа. 2011. № 4 (76). С. 24-28.

\section{References:}

1. Hubar, O.Ye. (2012). Sotsialne strakhuvannia u zabezpechenni suspilnoho dobrobutu [Social insurance in ensuring public welfare]. Finansy Ukrainy - Finance of Ukraine, 8, 130-136 [in Ukrainian].

2. Dymnich, O.V. (2015). Systema sotsialnoho strakhuvannia ta shliakhy yii udoskonalennia v Ukraini [The system of social insurance and ways its improvement in Ukraine]. Extended abstract of candidate's thesis. Kyiv [in Ukrainian].

3. Dymnich, O.V. (2013). Stanovlennia system sotsialnoho zakhystu hromadian na strakhovykh zasadakh $\mathrm{v}$ promyslovo rozvynenykh krainakh [Formation of social protection systems for citizens on an insurance basis in industrialized countries]. Nauka ta ekonomika - Science and economics, 4(2), 13-19 [in Ukrainian].

4. Kyrylenko, O.P., Tolubiaka, V.S. (2016). Sotsialne strakhuvannia [Social insurance]. Ternopil: Ekon. dumka TNEU [in Ukrainian].

5. Koval, O.P. (2014). Modernizatsiia systemy sotsialnoho strakhuvannia $v$ Ukraini [Modernization of the social insurance system in Ukraine: an analytical report]. Kyiv: NISD [in Ukrainian]. 
6. Kryvoshlyk, T.D. (2018). Vplyv tendentsii sotsialnoho strakhuvannia na rozvytok systemy strakhovoho zakhystu v Ukraini [The impact of social insurance trends on the development of the insurance system in Ukraine]. Biznes inform - Business inform, 12, 239-245. Retrieved from https://www.businessinform.net/export_pdf/business-inform-2018-12_0-pages-239_245.pdf [in Ukrainian].

7. Kropelnytska, S.O., Solodzhuk, T.V. (2013). Sotsialne strakhuvannia [Social insurance]. Kyiv: Tsentr uchbovoi literatury [in Ukrainian].

8. Makarova, O.V. (2015). Sotsialna polityka v Ukraini [Social policy in Ukraine]. Kyiv: In-t demohrafii ta sotsialnykh doslidzhen im. M. V. Ptukhy NAN Ukrainy [in Ukrainian].

9. Zakon Ukrainy "Pro strakhuvannia" : vid 07.03.1996, № 85/96-VR [Law of Ukraine "On insurance" from 07.03.1996, №85/96-BP]. zakon.rada.gov.ua. Retrieved from https://zakon.rada.gov.ua/laws/show/85/96-\%D0\%B2\%D1\%80\#Text [in Ukrainian].

10. Servatynska, I.M. (2016). Finansove zabezpechennia funktsionuvannia derzhavnykh fondiv sotsialnoho strakhuvannia [Financial support of functioning of state funds of social insurance]. Candidate's thesis. Cherkasy [in Ukrainian].

11. Skurativskyi, V.A., Palii, O.M. (2010). Osnovy sotsialnoi polityky [Fundamentals of social policy]. Kyiv: Mizhrehionalna akademiia upravlinnia personalom [in Ukrainian].

12. Ustynov, S.O. (2011). Spivvidnoshennia terminiv «sotsialnyi zakhyst» ta «sotsialne zabezpechennia» $\mathrm{v}$ zakonodavstvi Ukrainy [The ratio of the terms "social protection" and "social security" in the legislation of Ukraine]. Yurydychna nauka i praktyka - Legal science and practice, 2, 90-95 [in Ukrainian].

13. Shulha, N.V. (2011). Spivvidnoshennia poniat «sotsialne zabezpechennia» ta «sotsialnyi zakhyst» [The ratio of the concepts of "social security" and "social protection"]. Mytna spravaCustoms business, 4(76), 24-28 [in Ukrainian]. 